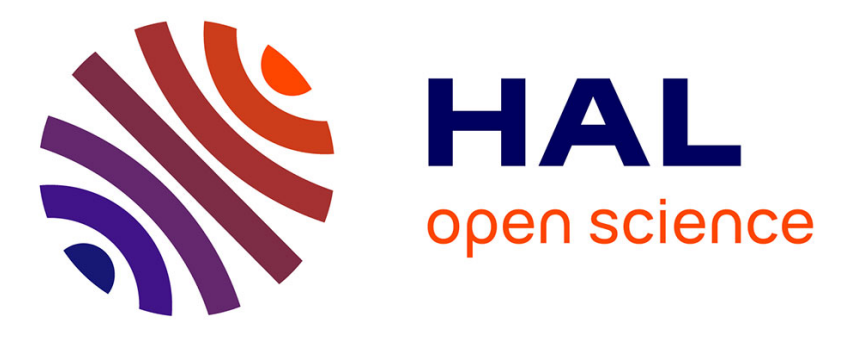

\title{
Ingestion of charcoal by the Amazonian earthworm Pontoscolex corethrurus: a potential for tropical soil fertility
}

Jean-François Ponge, Stéphanie Topoliantz, Sylvain Ballof, Jean-Pierre Rossi, Patrick Lavelle, Jean-Marie Betsch, Philippe Gaucher

\section{To cite this version:}

Jean-François Ponge, Stéphanie Topoliantz, Sylvain Ballof, Jean-Pierre Rossi, Patrick Lavelle, et al.. Ingestion of charcoal by the Amazonian earthworm Pontoscolex corethrurus: a potential for tropical soil fertility. Soil Biology and Biochemistry, 2006, 38 (7), pp.2008-2009. 10.1016/j.soilbio.2005.12.024 . hal-00495398

\section{HAL Id: hal-00495398 \\ https://hal.science/hal-00495398}

Submitted on 25 Jun 2010

HAL is a multi-disciplinary open access archive for the deposit and dissemination of scientific research documents, whether they are published or not. The documents may come from teaching and research institutions in France or abroad, or from public or private research centers.
L'archive ouverte pluridisciplinaire HAL, est destinée au dépôt et à la diffusion de documents scientifiques de niveau recherche, publiés ou non, émanant des établissements d'enseignement et de recherche français ou étrangers, des laboratoires publics ou privés. 
1 Type of contribution: Letter to the Editor

2 Date of preparation: 19 December 2005

$3 \quad$ Number of text pages: 5

4

5 Title: Ingestion of charcoal by the Amazonian earthworm Pontoscolex corethrurus: a 6 potential for tropical soil fertility

7

8 Jean-François Ponge ${ }^{1 *}$, Stéphanie Topoliantz ${ }^{1}$, Sylvain Ballof ${ }^{2}$, Jean-Pierre Rossi ${ }^{3}$, Patrick

9 Lavelle $^{4}$, Jean-Marie Betsch ${ }^{5}$, Philippe Gaucher ${ }^{6}$

10

$11{ }^{1}$ Muséum National d'Histoire Naturelle, CNRS Unité Mixte de Recherches 5176, 91800

12 Brunoy, France

$13{ }^{2}$ Office National des Forêts, 97370 Maripasoula, Guyane Française

$14{ }^{3}$ Institut National de la Recherche Agronomique, INRA, Unité Mixte de Recherches BIOGECO, 33612 Cestas Cédex, France

$16{ }^{4}$ Institut de Recherche pour le Développement, Unité Mixte de Recherches BIOSOL 137, 1793143 Bondy Cédex, France

18 5 Muséum National d'Histoire Naturelle, Unité Scientifique 306, 91800 Brunoy, France

\footnotetext{
* Correspondence: Jean-François Ponge, Muséum National d'Histoire Naturelle, CNRS UMR 5176, 4 avenue du Petit-Château, 91800 Brunoy, France, E-mail: jean-francois.ponge@ wanadoo.fr
} 
It is now attested that a large part of the Amazonian rain forest has been cultivated during Pre-Colombian times, using charcoal as an amendment. The incorporation of charcoal to the soil is a starting point for the formation of fertile Amazonian Dark Earths, still selected by Indian people for shifting cultivation. We showed that finely separated charcoal was commonly incorporated in the topsoil by Pontoscolex corethrurus, a tropical earthworm which thrives after burning and clearing of the rain forest, and that this natural process could be used to improve tropical soil fertility. Our paper is a contribution to the present debate about (i) the origin of black carbon in fertile Dark Earths, (ii) the detrimental vs favourable role of Pontoscolex corethrurus in tropical agriculture, (iii) natural processes which might be used to increase tropical soil fertility

Keywords: Tropical earthworms, Tropical soil fertility, Slash-and-burn agriculture, Charcoal

Pontoscolex corethrurus (Annelida: Oligocheata: Glossoscolecidae) is a small terrestrial earthworm which commonly inhabits rain forest soils over the whole Amazonian basin (Römbke et al., 1999). Its important burrowing activity through the topsoil, associated with its efficient digestive system (Zhang et al., 1993; Barros et al., 2001), allows it to thrive in soils poor in organic matter, such as those found in areas now deforested for the need of agriculture. In the absence of organic input to the soil, excessive casting activity of this species may cause damage to permanent pastures through the coalescence of earthworm casts, leading to appearance of a thick compact surface crust (Chauvel et al., 1999). However, the detrimental influence of this species may be questioned when the agricultural use of the land is only temporary, as in slash-and-burn shifting agriculture, or when available carbon is 
1 regularly added to the soil. We hypothesized that $P$. corethrurus could be responsible for the

2 observed increase in soil fertility which has been reported to occur in Amazonian Dark Earths

3 formed during Pre-Colombian times (Myers et al., 2003; Steiner et al., 2004).

4

Using a quantitative optical method (Topoliantz et al., 2000), we investigated the

6 distribution of humus components in soils under shifting cultivation, still practised by

7 Wayana and Aluku people settled along the Maroni river, French Guiana (Topoliantz et al.,

2005b). This method allowed us to estimate the relative volume of components of the soil

matrix, including plant tissues at varying stages of decomposition, mineral particles of varying size and nature, aggregates of varying colour, size and shape.

The untouched old forest exhibited low contents of both charcoal and charred material, representing $2 \%$ and $7 \%$ of the volume of the soil matrix, respectively. We showed that six months after burning of the same forest for cultivation, the contents of charcoal and charred material increased to $10 \%$ and $20 \%$ of the soil matrix, respectively, in the top $3 \mathrm{~cm}$. After three years of cultivation these amounts decreased to $6 \%$ and $15 \%$, respectively. During the cultivation period the amount of dark humus (mixture of charcoal and mineral soil in varying proportion) increased steadily. The examination of dark humus revealed that it was mainly comprised of faecal pellets of $P$. corethrurus, which contained a multitude of small charcoal fragments of $10-100 \mu \mathrm{m}$ admixed in a mineral paste.

Charcoal, ingested together with soil particles, is mixed with mucus secreted in the oesophagus then finely ground in the muscular gizzard of earthworms. It is excreted as a muddy paste which is further stabilized by Van der Wals forces after drying, thus forming dark humus (Hayes, 1983). We also showed by laboratory experiments that $P$. corethrurus did 
not ingest charcoal alone but rather added it to mineral soil. A mixture of charcoal and soil

2 was preferred to either pure charcoal or pure soil (Topoliantz and Ponge, 2003, 2005a). This

3 points to a positive feed-back which improves the habitat of $P$. corethrurus by increasing the

4 carbon content of the soil.

It has been demonstrated that finely divided charcoal (also called black carbon) was a

7 source of stable humus (Tryon, 1948; Chan et al., 1999). Slow oxidation and hydroxylation

8 increase donor/acceptor charges, giving the soil strong exchangeable properties. The positive

9 impact of charcoal in ameliorating the physical and chemical properties of tropical soils has

10 been reported in various situations (Glaser et al., 2002). To the light of our results we expect

11 the peregrine earthworm $P$. corethrurus to be the main agent for the incorporation of charcoal

12 to the topsoil in the form of fine particles of silt size, which favoured the formation of stable

13 humus in Amazonian Dark Earths or 'Terra Preta' during Pre-Colombian times (Glaser et al., 14 2000).

The natural development of $P$. corethrurus, able to feed and reproduce in tropical soils 17 poor in organic matter, opens avenues for new agricultural practices better adapted to 18 permanent settlements, using charcoal in mixture with nutrient-rich amendment (Steiner et al., 19 2004). In situ experiments were conducted with the help of a local agriculturist at Maripasoula 20 (French Guiana), using waste products of slash-and-burn agriculture (charcoal and manioc 21 peels) as an amendment. We demonstrated that the addition of charcoal together with manioc 22 peels, known to be rich in phosphorus (a limiting nutrient in tropical soils), increased yard23 long bean production at the natural population size of $P$. corethrurus, thus allowing 24 diversification of family agriculture without any additional cost (Topoliantz et al., 2002;; 25 Topoliantz et al., 2005). 


\section{Acknowledgements}

3

4 This work was supported by the French Ministry of Ecology and Sustainable Development 5 (SOFT program) and by a grant from the Commission for the Creation of the Guiana Natural 6 Park. The authors warmly acknowledge Dr. C. Kerdelhué (INRA, Pierroton, France) and Dr.

7 L. Greenfield (Canterbury University, Christchurch, New Zealand) for language editing.

\section{References}

Barros, E., Curmi, P., Hallaire, V., Chauvel, A., Lavelle, P., 2001. The role of macrofauna in the transformation and reversibility of soil structure of an Oxisol in the process of forest to pasture conversion. Geoderma 100, 193-213.

14

Chan, M.L., Jones, J.M., Pourkashanian, M., Williams, A., 1999. The oxidative reactivity of coal chars in relation to their structure. Fuel 78, 1539-1552.

17

Chauvel, A., Grimaldi, M., Barros, E., Blanchart, E., Desjardins, T., Sarrazin, M., Lavelle, P., 1999. Pasture damage by an Amazonian earthworm. Nature 398, 32-33.

Glaser, B., Balashov, E., Haumaier, L., Guggenberger, G., Zech, W., 2000. Black carbon in density fractions of anthropogenic soils of the Brazilian Amazon region. Organic Geochemistry 31, 669-678. 
1 Glaser, B., Lehmann, J., Zech, W., 2002. Ameliorating physical and chemical properties of hughly weathered soils in the tropics with charcoal. A review. Biology and Fertility of Soils 35, 219-230.

Hayes, M.H.B., 1983. Darwin's "vegetable mould" and some modern concepts of humus structure and soil aggregation. In: Satchell, J.E. (Ed.), Earthworm Ecology from Darwin to Vermiculture. Chapman and Hall, London, pp. 19-33.

Myers, T.P., Denevan, W.M., Winklerprins, A., Porro, A., 2003. Historical perspectives on Amazonian Dark Earths. In: Lehmann, J., Kern, D.C., Glaser, B., Woods, W.I. (Eds.), Amazonian Dark Earths. Origin, Properties, Management. Kluwer, Dordrecht, pp. 1528.

Römbke, J., Meller, M., García, M., 1999. Earthworm densities in central Amazonian primary and secondary forests and a polyculture forestry plantation. Pedobiologia 43, 518-522.

Steiner, C., Teixeira, W.G., Zech, W., 2004. Slash and char: an alternative to slash and burn practiced in the Amazonian Basin. In: Glaser, B., Woods, W.I. (Eds.), Amazonian Dark Earths: Explorations in Space and Time. Springer, Berlin, pp. 183-193.

Topoliantz, S., Ponge, J.F., 2003. Burrowing activity of the geophagous earthworm Pontoscolex corethrurus (Oligochaeta: Glossoscolecidae) in the presence of charcoal. Applied Soil Ecology 23, 267-271. 
1 Topoliantz, S., Ponge, J.F., 2005. Charcoal consumption and casting activity by Pontoscolex corethrurus (Glossoscolecidae). Applied Soil Ecology 28, 217-224.

3

4 Topoliantz, S., Ponge, J.F., Arrouays, D., Ballof, S., Lavelle, P., 2002. Effect of organic 5 manure and the endogeic earthworm Pontoscolex corethrurus (Oligochaeta: Glosscoscolecidae) on soil fertility and bean production. Biology and Fertility of Soils 36, 313-319.

Topoliantz, S., Ponge, J.F., Ballof, S., 2005a. Manioc peel and charcoal: a potential organic amendment for sustainable soil fertility in the tropics. Biology and Fertility of Soils 41, 15-21.

Topoliantz, S., Ponge, J.F., Lavelle, P., 2005b. Humus components and biogenic structures under tropical slash-and-burn agriculture. European Journal of Soil Science doi: 10.1111/j.1365-2389.2005.00736.x (on line first).

Tryon, E.H., 1948. Effect of charcoal on certain physical, chemical, and biological properties of forest soils. Ecological Monographs 18, 81-115. 
1 Zhang, B.G., Rouland, C., Lattaud, C., Lavelle, P., 1993. Activity and origin of digestion complexes in gut of the tropical earthworm Pontoscolex corethrurus. European Journal of Soil Biology 29, 7-11. 